\title{
Cell-Free Synthesis and Affinity Isolation of Proteins on a Nanomole Scale
}

BioTechniques 28:338-344 (February 2000)

\begin{abstract}
A.P. Alimov, A.Yu. Khmelnitsky, P.N. Simonenko, A.S. Spirin and A.B. Chetverin Institute of Protein Research, Russian Academy of Sciences, Pushchino, Moscow Region, Russia
\end{abstract}

\section{INTRODUCTION}

Cell-free translation is a powerful tool for studying gene expression. It would be desirable to use cell-free translation systems as a source of proteins for biochemical and molecular biology studies. The expensive continuous flow cell-free $(\mathrm{CFCF})$ reactors $(26,32,33)$ or dialysis cells $(15,16)$ can produce milligrams of a protein per $1 \mathrm{~mL}$ of reaction volume. However, many research laboratories need only smaller amounts. The goal of this study was to improve the performance of a conventional microcentrifuge tube reaction so that a substantial amount of a protein could be rapidly synthesized and isolated at a low cost by using the standard components readily available on the market.

A higher-performance, cell-free system can be achieved by manipulating the system composition (12-14,17). However, such improvements often lead to an increase in the system cost that is comparable with the increase in the protein yield. On the other hand, our previous observations indicated that the performance of a standard cellfree system could be greatly improved solely by manipulating the untranslated regions of mRNA templates. For example, embedding an mRNA into the genomic RNA of Q $\beta$ phage in place of its coat protein cistron enhanced the mRNA translation by up to two orders of magnitude (11). However, Q $\beta$ RNA is too large $(>4.2 \mathrm{~kb})$ and includes other concurrently translated viral cistrons. We decided to approach the goal from another end, by constructing a vector possessing only short essential virus- specific structural elements.

The vectors reported here (Figure 1) are suitable for gene expression in the bacterial cell-free systems and encode the following structural elements of Escherichia coli phages: $(i)$ the promoter of phage T7 RNA polymerase, one of the most potent and selective RNA polymerases (34); (ii) the $133 \mathrm{nu}$ cleotide long cDNA sequence of an RQ RNA (RQ135-1 RNA) (21), a Q $\beta$ phage satellite RNA (5) that can be amplified by $\mathrm{Q} \beta$ replicase (the $\mathrm{RNA}$-directed RNA polymerase of phage $Q \beta$ ) (6) with a strong secondary structure that resembles the terminal structures of the genomic $Q \beta$ RNA $(1,4,6)$. Insertion of an mRNA into an RQ RNA (an RNA that is replicable by $Q \beta$ replicase) (21) enhances the expression of that mRNA by making it amplifiable by $\mathrm{Q} \beta$ replicase in the presence of a coupled translation system $(20,25)$ and protecting it from ribonucleases (35); (iii) the Epsilon (E) sequence, a powerful translational enhancer of phage T7 coat protein gene 10 , which is also present in the initiator region of the coat protein cistron of Q $\beta$ RNA (23). These viral elements were expected to enhance the expression of a harbored gene in a translation, transcription-translation, or replication-translation, cell-free system based on the crude (S30) E. coli extract.

Also, the vectors contain a sequence coding for Strep-tag (ST), an oligopeptide selected for possessing a moderate affinity to streptavidin $\left[\mathrm{K}_{\mathrm{d}}\right.$ ca. $10^{-5} \mathrm{M}$ $(28,29)]$. Proteins fused to ST at the Cterminus can be affinity purified on a streptavidin-agarose column under mild conditions (30). 
We show here that using these vectors in the standard cell-free expression systems provides for the synthesis of up to $40 \mu \mathrm{g}$ of an active ST-fused protein per $1 \mathrm{~mL}$ of reaction mixture and that the synthesized protein can be efficiently isolated on an affinity column.

\section{MATERIALS AND METHODS}

\section{Plasmids}

Plasmid pASK-IBA1 (Institut für Bioanalytik, Göttingen, Germany) was used as a source of the ST-coding sequence, which was PCR-amplified with primers 1 (5'-TTCTCGAGGTAACATATGGGCCATGGTCTCAGCGCTTGGC-3', introducing the upstream XhoI and $N d e I$ sites, underlined) and 2 (5'-CCCTCGAGTTAACCACCGAACTG-
CGGGTGA-3', introducing the downstream XhoI site). Plasmid pRQST was obtained by ligating the XhoI-digested PCR product at site XhoI of a pUC18derived plasmid pRQXhoI (Reference 20 and Figure 1) with its site $\mathrm{NdeI}$ at position 183 of the original pUC18 vector eliminated. Plasmid pRQSTE was prepared by PCR amplification of the ST-coding sequence using pRQST as a template and primers 2 and $3\left(5^{\prime}\right.$ TTCTCGAGGTTAACTTTACCAAGAGGTAACATATGGGCCATGGTCTCA-3', introducing the E sequence) (23) and ligating the XhoI- digested PCR product at site $X h o I$ of $\mathrm{pRQXhoI}$.

Plasmid pSP65DHFR 0.7 (20) was used as a source of E. coli dihydrofolate reductase (DHFR) gene that was PCR-amplified with primers $4\left(5^{\prime}\right.$ GGCATATGATCAGTCTGATTGCGGCGT-3', introducing site NdeI at the beginning of the coding sequence) and 5 (5'-GACCATGGCCCCGCCGCTCCAGAATCTCA-3' and introducing site $N c o$ I at the end of the coding sequence). The NdeI/NcoI-digested PCR product was ligated between these sites into plasmids pRQST and pRQSTE, resulting in plasmids pRQST-DHFR and pRQSTE-DHFR, respectively (Figure 1). Plasmid pRQSTEP-DHFR was obtained by PCR amplifying the STEDHFR insert of pRQSTE-DHFR with primers 6 [5'-CTTCTCGAGCTTAACTTTAGTAGGAGGTATCATATG-3', slightly changing the $5^{\prime}$ untranslated region (UTR)] and 7 (5'-TCCCTCGAGGGCAGTTCGGTTTAACCACCGAACTGCGGGT-3', introducing the anti-ST sequence, underlined) and ligating the XhoI-digested PCR product into site XhoI of pRQXhoI.

Plasmid pBAD-GFP (Maxygen,

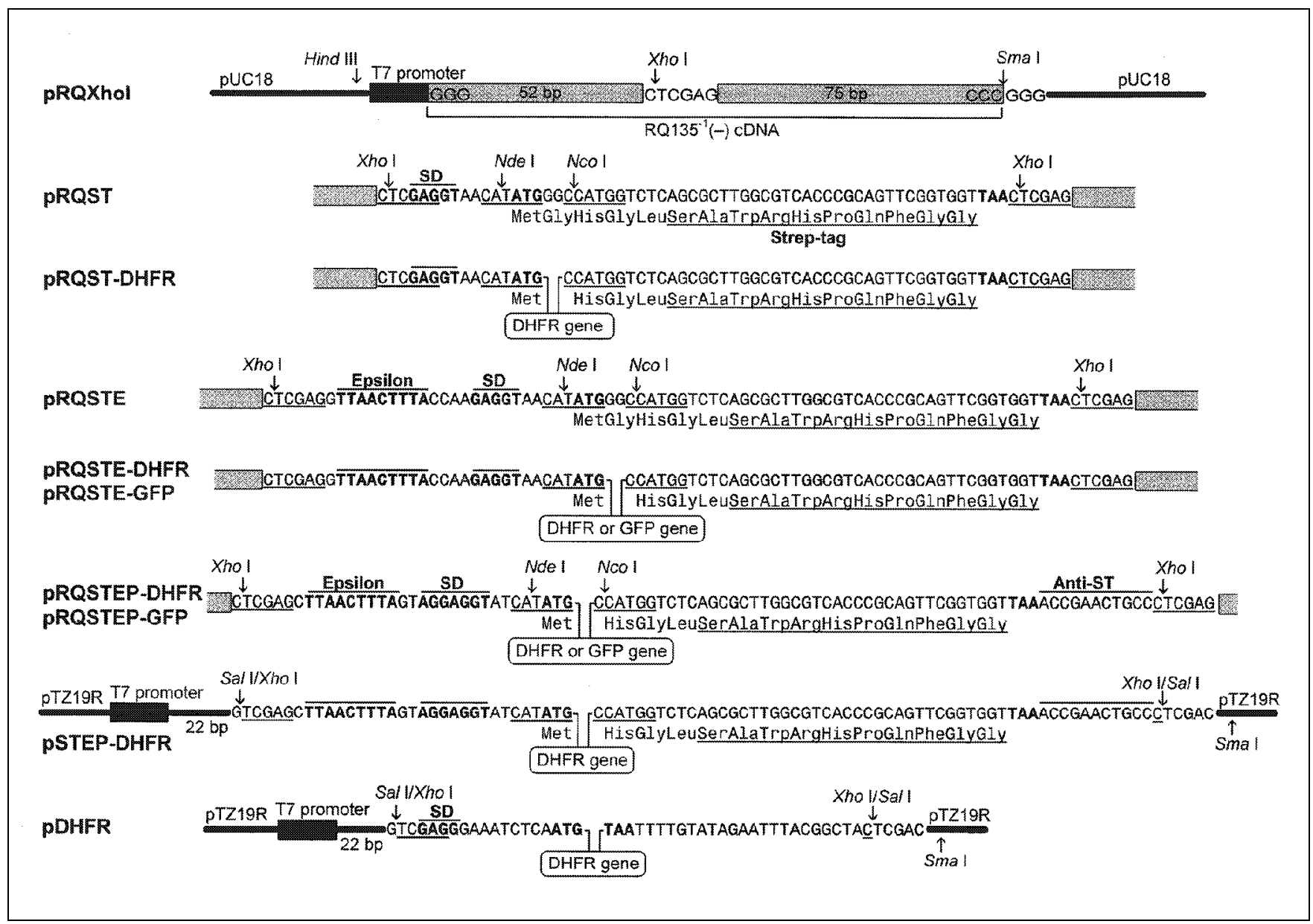

Figure 1. Schematic presentation of the expression vectors. Important restriction sites are underlined; E and Shine-Delgarno sequences, as well as the initiator and terminator codons are shown in bold; gray bars indicate RQ elements. In the plasmid names, "RQ" stands for RQ sequence, "ST" for Strep-tag, E for the Epsilon sequence and "P" for plus. 
Redwood City, CA, USA) was used as a source of Aequorea victoria green fluorescent protein (GFP) gene (Cycle 3 mutant), which was PCR-amplified with primers 8 (5'-GATATACATATGGCTAGCAAAGGAGAAGAAC-3'. This primer fully matched the template and contained site NdeI) and $9\left(5^{\prime}\right.$ GACCATGGCCTTTGTAGAGCTCATCCATGCCATG-3', introducing the downstream NcoI site). Since the GFP gene itself contains sites NdeI and NcoI, the PCR product was first cloned, after removing the overhanging $\mathrm{A}$ with T4 DNA polymerase and phosphorylating, at site PvuII of pGEM2 (Promega, Madison, WI, USA). The NdeI/NcoI fragment of an appropriate size was then obtained by a limited digestion and agarose electrophoresis, and was then ligated between these sites into plasmids pRQSTE-DHFR and pRQSTEP-DHFR, resulting in plasmids pRQSTE-GFP and pRQSTEPGFP, respectively (Figure 1).

Plasmids pSTEP-DHFR lacking the RQ135 sequences and pDHFR lacking both the RQ135 and STEP sequences

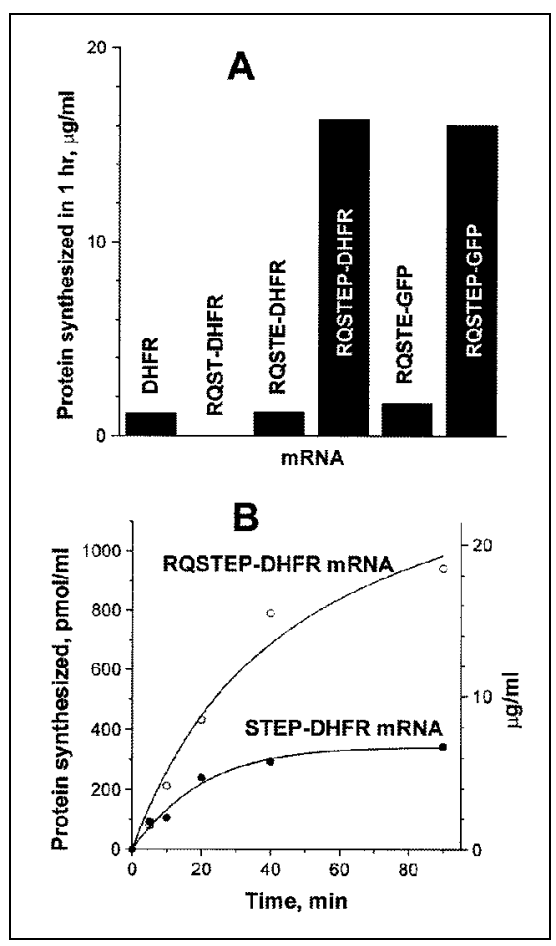

Figure 2. Protein synthesis in the translation system. (A) Performance of mRNAs differing by structural elements in the untranslated regions (cf. Figure 1). (B) Time course of DHFR synthesis on mRNAs possessing and lacking the RQ elements.
(Figure 1) were prepared by excising the XhoI fragments from pRQSTEPDHFR and pT7RQ135-1(-)DHFR(+) (20), respectively, and recloning them at site SalI of pTZ19R (Amersham Pharmacia Biotech, Piscataway, NJ, USA) downstream from the $\mathrm{T} 7$ promoter.

\section{Cell-Free Reactions}

SmaI-digested plasmids were transcribed with T7 RNA polymerase (8). Cell-free translations were carried out in microcentrifuge tubes at $37^{\circ} \mathrm{C}$ in a medium containing $30 \%$ (vol/vol) S30 extract prepared (37) from E. coli A19 cells [ca. $2 \mathrm{nmol} / \mathrm{mL}$ final ribosome concentration), $100 \mathrm{mmol} / \mathrm{L}$ HEPES$\mathrm{KOH}, \mathrm{pH}$ 7.6, $1 \mathrm{mmol} / \mathrm{L}$ EDTA, 2 $\mathrm{mmol} / \mathrm{L}$ dithiothreitol, 4\% glycerol, $0.03 \% \mathrm{NaN}_{3}, 18 \mathrm{mmol} / \mathrm{L} \mathrm{Mg}(\mathrm{OAc})_{2}$, $120 \mathrm{mmol} / \mathrm{L} \mathrm{KOAc}, 2 \mathrm{mmol} / \mathrm{L}$ ATP, 1.6 $\mathrm{mmol} / \mathrm{L}$ GTP, $0.2 \mathrm{mmol} / \mathrm{L}$ each of amino acids (leucine omitted), 0.1 $\mathrm{mmol} / \mathrm{L}\left[{ }^{14} \mathrm{C}\right]$ leucine at a specific activity of $38 \mathrm{mCi} / \mathrm{mmol}, 0.01 \mathrm{mg} / \mathrm{mL}$ folinic acid, $0.5 \mathrm{mg} / \mathrm{mL}$ total $E$. coli tRNA, $800 \mathrm{pmol} / \mathrm{mL}$ mRNA, 160 U/mL RNase inhibitor (Roche Molecular Biochemicals, Mannheim, Germany) and $40 \mathrm{mmol} / \mathrm{L} \mathrm{Li}, \mathrm{K}$-acetylphosphate (served as a phosphate donor for endogenous kinases that regenerate NTPs) (24). A transcription-translation cocktail contained additionally 1 $\mathrm{mmol} / \mathrm{L}$ CTP, $1 \mathrm{mmol} / \mathrm{L}$ UTP, 3000 $\mathrm{U} / \mathrm{mL}$ T7 RNA polymerase and 40 $\mu \mathrm{g} / \mathrm{mL}$ (ca. $20 \mathrm{pmol} / \mathrm{mL}$ ) of a covalently closed circular plasmid instead of mRNA. The amount of synthesized protein (expressed in $\mathrm{pmol} / \mathrm{mL}$ or $\mu \mathrm{g} / \mathrm{mL}$ ) was assessed by measuring the trichloroacetic acid-insoluble radioactivity in $5 \mu \mathrm{L}$ aliquots at the indicated time points. The measurements took into account the number of Leu residues (11 in DHFR and 19 in GFP, plus 1 in the ST extension) and the molecular mass of the protein $(18 \mathrm{kDa}$ for DHFR and $26.98 \mathrm{kDa}$ for GFP, plus $1.49 \mathrm{kDa}$ for the ST extension).

\section{Affinity Isolation of Proteins}

Strep-tag-fused proteins were isolated from $0.5 \mathrm{~mL}$ of a cell-free system using the Strep-tag ${ }^{\circledR}$ kit (Institute für Bioanalytik) according to the manufacturer's protocol. Briefly, a sample was applied to a $0.5 \mathrm{~mL}$ streptavidinagarose column, followed by $3 \mathrm{~mL}$ of the washing buffer $(100 \mathrm{mmol} / \mathrm{L}$ Tris$\mathrm{HCl}, \mathrm{pH} 8.0,1 \mathrm{mmol} / \mathrm{L}$ EDTA, $0.02 \%$ $\mathrm{NaN}_{3}$ ). The bound protein was then eluted by the same buffer containing 3 $\mathrm{mmol} / \mathrm{L}$ diaminobiotin and collected in $0.5 \mathrm{~mL}$ fractions.

\section{RESULTS AND DISCUSSION}

\section{Vector Design}

As a starting vector, we used plasmid pRQXhoI, which already contained RQ135-1 cDNA downstream from the $\mathrm{T} 7$ promoter and whose RQ sequence was mutated to introduce a unique $\mathrm{XhoI}$ site convenient for insertion of foreign sequences (20). The plasmid was modified to introduce a Shine-Dalgarno sequence (31), the initiator codon, the ST-coding sequence (pRQST series) and the E sequence (pRQSTE series) and then used for the cloning of DHFR and GFP genes (Figure 1). The pRQSTEP plasmids also contained in the $3^{\prime}$ UTR a short oligonucleotide complementary to the ST-coding sequence (anti-ST sequence). The vector construction allows any gene, after it has been PCRamplified with a pair of appropriate primers, to be inserted between sites $\mathrm{NdeI}$ and $\mathrm{NcoI}$ in frame with the downstream ST-coding sequence. The resulting protein is fused at its $\mathrm{C}$-terminus to the ST peptide using tetrapeptide GlyHis-Gly-Leu (Figure 1).

\section{Vector Performance in the Translation System}

The SmaI-runoff transcripts of the plasmids obtained were tested in a cellfree translation system (Figure 2). Earlier, we found that insertion of the DHFR gene into the RQ sequence resulted in a threefold enhancement of its expression due to a higher mRNA stability in the S30 translation system (35). Surprisingly, introduction of STcoding sequence to the RQ-DHFR mRNA resulted in a null translation (Figure 2A, RQST-DHFR mRNA). Further addition of the $\mathrm{E}$ sequence revived the template (Figure 2A, RQSTE-DHFR mRNA), but its transla- 
tional activity was not higher than that of the authentic DHFR mRNA (Figure 2A) that lacked the RQ, ST and E sequences (Figure 1, pDHFR).

Figure 3 shows that the last portion of the ST-coding sequence is capable of forming base pairs with the initiator region of mRNAs containing the ShineDalgarno and E sequences. This could explain the observed inhibition of translation. A similar hiding of the initiator region within RNA secondary structure results in a complete suppression of translation of the A cistron of RNA coliphages (4).

To test this hypothesis, we introduced, just downstream from the terminator codon, UAA, an 11-nucleotide

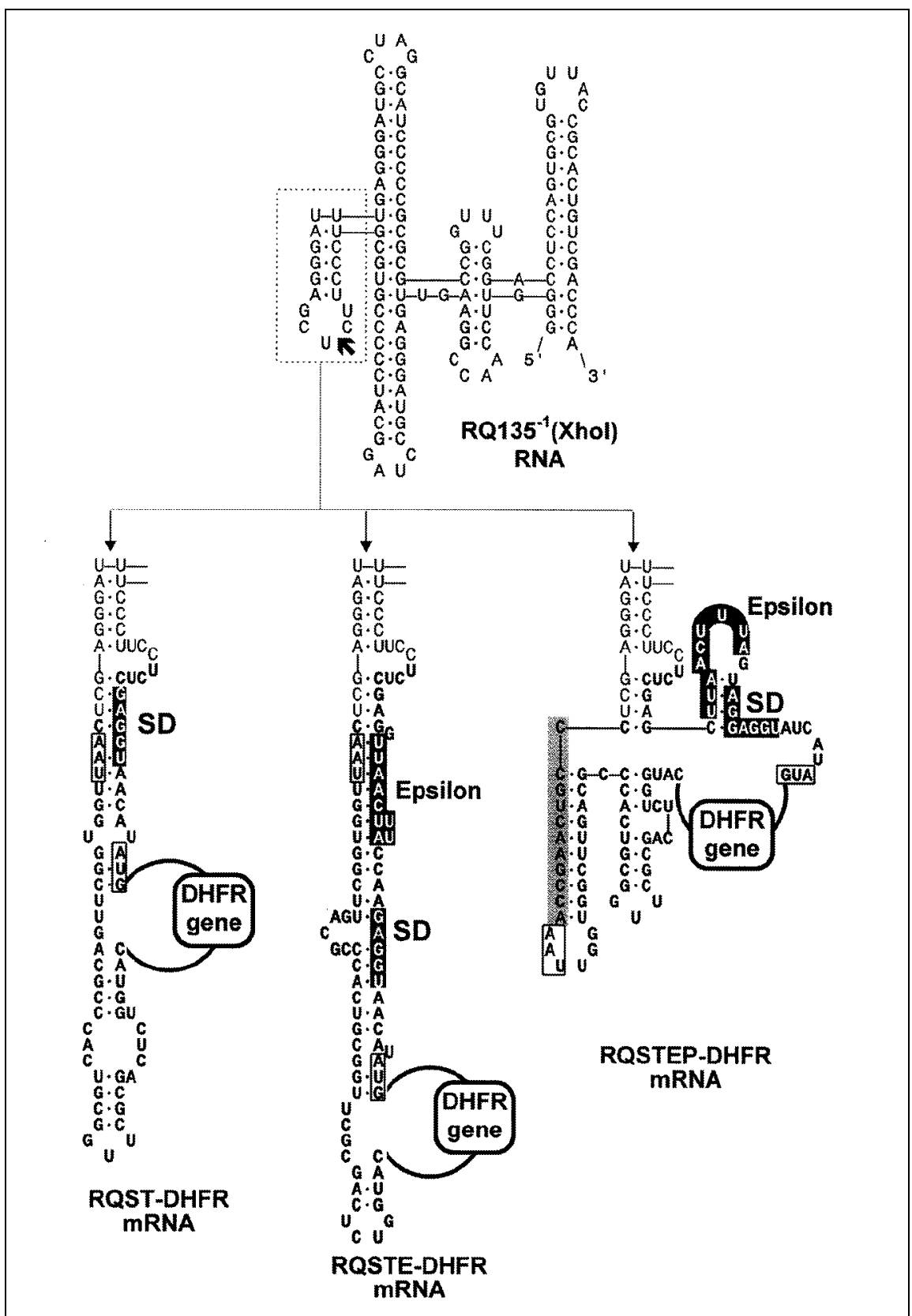

Figure 3. Possible secondary structure of the RQ moiety (upper panel) and of mRNA inserts within the RQST, RQSTE and RQSTEP vectors (lower panel). Arrow indicates the site in the RQ RNA sequence where mRNAs are inserted. The inserted sequences are shown in bold; E and Shine-Dalgarno sequences are shown on a black background; initiator (AUG) and terminator (UAA) codons are boxed; the anti-ST sequence is shown on a gray background. Secondary structures were predicted online at http://www.ibc.wustl.edu/ zuker/ by program MFOLD 3.0 based on free energy minimization (9). 
long segment complementary to the interfering part of the ST-coding sequence (anti-ST sequence). We expected that the anti-ST sequence would distract the ST-coding sequence from the E and Shine-Dalgarno sequences (Figure 3) and would thereby unblock the initiation of translation. We also introduced into the translation leader sequence a few nucleotide substitutions to additionally weaken the RNA secondary structure in the initiator region. The resulting vector was designated pRQSTEP (Figure 1). Figure 2A demonstrates that these minor changes
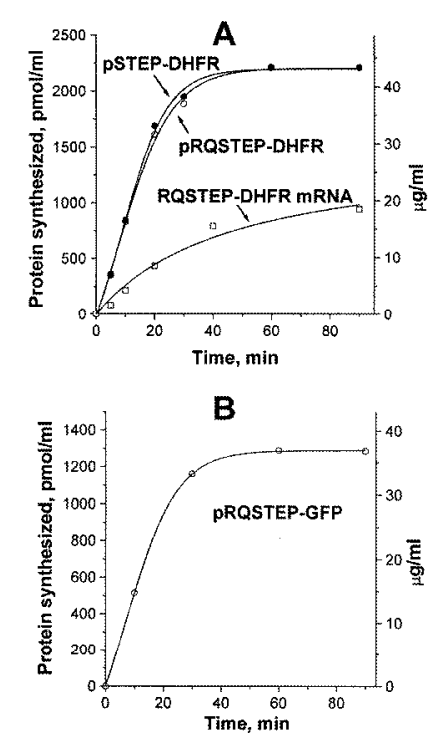

C

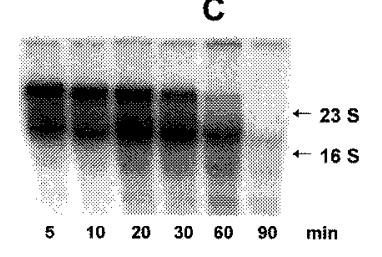

Figure 4. Protein synthesis in the coupled transcription-translation system. (A) Comparison of the kinetics of DHFR synthesis on a plasmid (with or without the RQ moiety) with that on an mRNA. (B) Time course of GFP synthesis. (C) RNA synthesized during the reaction displayed in Panel B. To monitor the RNA, a part of the reaction mixture was supplied with $\left[{ }^{32} \mathrm{P}\right] \mathrm{ATP}$, and phenol-extracted samples were analyzed by electrophoresis through a denaturing $5 \%$ polyacrylamide gel (27) and autoradiography. Arrows indicate the position of ribosomal RNA bands visible after staining the gel with toluidine blue. Since no transcriptional terminator was introduced behind the RQSTEP cassette (Figure 1), the size of synthesized RNAs was determined by terminators present in the pUC18 vector. in the vector structure resulted in a dramatic enhancement of translation. The enhancement was similar for DHFR and GFP templates (cf. RQSTE and RQSTEP mRNAs), as was the amount of synthesized protein. The translational potential of the pRQSTEP vector is comparable to that of $\mathrm{Q} \beta \mathrm{RNA}$ at its coat protein cistron (11), which is one of the most potent templates known; yet, it is a much simpler vector.

Figure 2B shows that the RQ moiety of the vector is responsible for about two-thirds of the translational activity of the RQSTEP-DHFR mRNA. With RQ elements, the protein synthesis lasted for a longer time, presumably due to the protection of mRNA against endogenous ribonucleases (35), and pro-

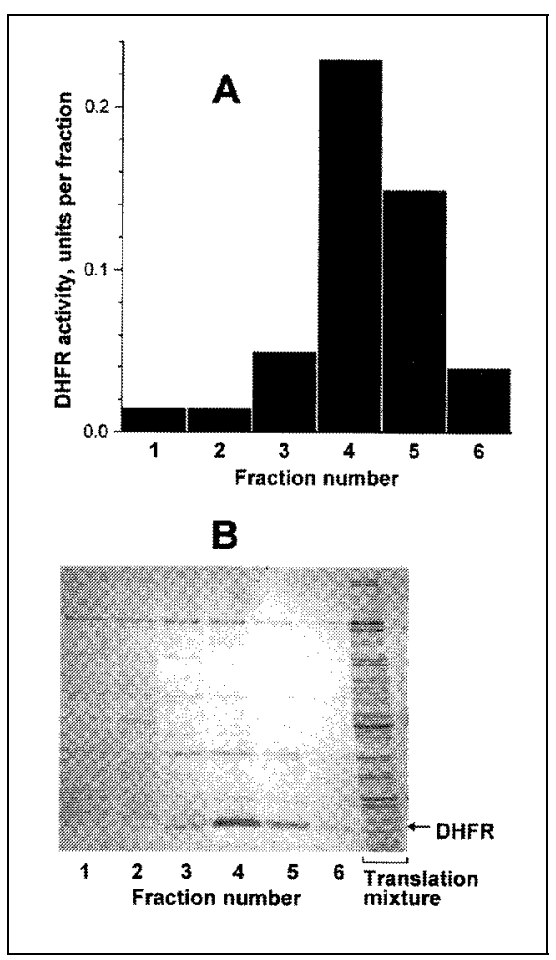

Figure 5. Affinity isolation of DHFR synthesized in the cell-free translation system. (A) Direct chromatography on a streptavidin-agarose column of $0.5 \mathrm{~mL}$ of the translation mixture containing $2.4 \mathrm{mg}$ of total protein (19) and $15.5 \mu \mathrm{g}$ (ca. $0.6 \%$ ) of ST-DHFR as determined by $\left[{ }^{14} \mathrm{C}\right]$ Leu incorporation. The increase of enzymatic activity (3) above that present in the E. coli extract $(0.06 \mathrm{U})$ was $0.82 \mathrm{U}$. About $35 \%$ of the starting DHFR activity was found in the flowthrough, and $61 \%(0.5 \mathrm{U})$ in fractions $3-6$. (B) Coomassie blue G-250 staining of the samples subjected to electrophoresis through a $10 \%-20 \%$ gradient polyacrylamide gel in the presence of SDS (18). Arrow indicates the position of the labeled band as revealed by autoradiography. duced approximately $20 \mu \mathrm{g}(1 \mathrm{nmol})$ of ST-DHFR per $1 \mathrm{~mL}$ of translation mixture by 90 min of incubation.

\section{Vector Performance in the Coupled Transcription-Translation System}

An even larger amount of a protein (ca. $40 \mu \mathrm{g} / \mathrm{mL}$ ) can be synthesized in a coupled transcription-translation system, in which T7 polymerase continuously transcribes plasmids of the pRQSTEP series (Figure 4, A and B). In the coupled system, the RNA stability is no longer a limiting factor: the same translation kinetics are observed with pRQSTEP and pSTEP plasmids (Figure 4A), and there is still a large amount of undegraded RNA at 30 min (Figure 4C) when protein synthesis ceases (Figure 4, A and B). The initial rate of protein synthesis in the coupled system is about $4 \times$ higher than in the translation system, but the final protein yield is only $2 \times$ as large because of the earlier plateau (Figure 4A). In the coupled system, the full-length RNA begins to disappear at the same time point when the protein plateau is reached (cf. Figure 4, B and C), which indicates that translation and transcription shut down simultaneously, probably due to the depletion of common substrates, NTPs. Indeed, in a CFCF reactor that is continuously fed with substrates, the RNA and protein syntheses remain steady for many hours (data not shown).

\section{Isolation of Proteins Synthesized in a Cell-Free System}

Proteins synthesized from pRQSTEP or $\mathrm{pSTEP}$ vectors can be isolated because of their affinity to streptavidin. Figure 5 shows an example of such an isolation. In this experiment, STDHFR synthesized on RQSTEPDHFR mRNA had a specific activity of $53 \mathrm{U} / \mathrm{mg}$, which is close to that of DHFR isolated from E. coli cells, 55 $\mathrm{U} / \mathrm{mg}$ (2). This result demonstrates that the in vitro synthesized protein is fully active and that the ST peptide does not affect the activity of DHFR. Figure 5 shows that a 100 -fold purification of ST-DHFR was achieved by single-step affinity chromatography on a streptavidin-agarose column, yielding $19 \mu \mathrm{g}$ $(0.95 \mathrm{nmol})$ of a relatively pure enzyme 
per $1 \mathrm{~mL}$ of translation mixture. Similar results were obtained with ST-GFP. Its activity was tested by its green fluorescence under a $366 \mathrm{~nm}$ light (data not shown). If needed, the isolated proteins can be further purified by HPLC or by gel electrophoresis.

\section{CONCLUSION}

This paper demonstrates that a significant enhancement of protein synthesis can be achieved in a standard cellfree system by solely manipulating the UTRs of an expression vector by introducing the viral structural elements known to enhance translation in vivo and to protect mRNA from ribonuclease action. The expression vectors reported here are universal in that they can be used, at a researcher's discretion, in a translation reaction or in a coupled transcription-translation reaction. The vectors can also be used in a coupled replication-translation reaction. It has been shown that embedding an mRNA into an RQ RNA sequence makes the former amplifiable by $\mathrm{Q} \beta$ replicase in the presence of a coupled translation system, resulting in a higher protein yield (20). Depending on the choice, $1 \mathrm{~mL}$ of a reaction yields $20-40$ $\mu \mathrm{g}$, or about $1 \mathrm{nmol}$ of a standard protein. This amount meets many needs of a research laboratory, such as exploring the enzymatic, ligand-binding or immunological properties of a protein or its ability to form complexes with other proteins or with nucleic acids.

In this study, we did not attempt to manipulate the system composition, but the data obtained indicate that a higher protein yield may be achieved by increasing the concentration of certain substrates (e.g., NTPs). The volume yield can also be increased by using condensed cell-free extracts $(15,17,22)$. If desired, the reported vectors can be used in a CFCF or dialysis-type protein synthesis reactors, in which one to two orders of magnitude larger amounts of a protein can be synthesized in the same volume using a continuous supply of substrates to the reaction mixture $(15,16,26,32,33)$.

The reported vectors allow any gene to be inserted between the initiator codon and the ST-coding sequence, so that its translation results in a functionally active protein carrying ST at the $\mathrm{C}$ terminus. The results demonstrate that such proteins can be easily isolated from the products of cell-free translation on a streptavidin-agarose column at a good yield and in a relatively pure state. Recently, a modified ST and a mutated streptavidin were reported that may further improve the purity of affinity isolated proteins (36). Of course, other fusion tags $(7,10)$ can also be used to recover the synthesized proteins.

Only one working day is required to carry out the entire procedure including the cell-free synthesis of a tagged protein and its affinity isolation. This may significantly advance any field in which rapid analysis of a gene expression product is important, such as screening the cDNA libraries, screening gene variants in protein engineering and functional identification of open reading frames whose sequences increasingly accumulate because of a progress in the genome projects.

\section{AKNOWLEDGMENTS}

We thank Dr. Herbert Stadler (Institute für Bioanalytik, Göttingen, Germany) for the gift of pASK-IBA1 and of a Strep-tag kit, and Oksana Kalita for technical assistance. This work was partially supported by Roche Molecular Biochemicals.

\section{REFERENCES}

1.Adhin, M.R., J. Alblas and J. van Duin. 1990. Secondary structures at the $3^{\prime}$ terminal region of RNA coliphages: comparison with tRNA. Biochim. Biophys. Acta 1050:110-118.

2.Baccanari, D.P., D. Averett and C. Briggs. 1977. Escherichia coli dihydrofolate reductase: isolation and characterization of two isozymes. Biochemistry 16:3566-3772

3.Baccanari, D.P. and S.S. Joyner. 1981. Dihydrofolate reductase hysteresis and its effect of inhibitor binding analyses. Biochemistry 20:1710-1716.

4.Beekwilder, J., R. Nieuwenhuizen, R. Poot and J. van Duin. 1996. Secondary structure model for the first three domains of $\mathrm{Q} \beta$ RNA. Control of A-protein synthesis. J. Mol. Biol. 256:8-19.

5.Chetverin, A.B., H.V. Chetverina and A.V. Munishkin. 1991. On the nature of spontaneous RNA synthesis by Q $\beta$ replicase. J. Mol. Biol. 222:3-9.

6.Chetverin, A.B. and A.S. Spirin. 1995. 
Replicable RNA vectors: prospects for cellfree gene amplification, expression and cloning. Prog. Nucleic Acid Res. Mol. Biol. 51:225-270.

7.Ford, C.F., I. Suominen and C.E. Glatz. 1991. Fusion tails for the recovery and purification of recombinant proteins. Protein Expr. Purif. 2:95-107.

8.Gurevich, V.V., I.D. Pokrovskaya, T.A. Obukhova and S.A. Zozulya. 1991. Preparative in vitro mRNA synthesis using SP6 and T7 RNA polymerases. Anal. Biochem. 195:207-213.

9.Jaeger, J.A., D.H. Turner and M. Zuker. 1990. Predicting optimal and suboptimal secondary structure for RNA. Methods Enzymol 183:281-306.

10.Jones, C., A. Patel, S. Griffin, J. Martin, P. Young, K. O'Donnell, C. Silverman, T. Porter and I. Chaiken. 1995. Current trends in molecular recognition and bioseparation. J. Chromatogr. A 707:3-22.

11.Katanaev, V.L., O.V. Kurnasov and A.S. Spirin. 1995. Viral Q $\beta$ RNA as a high expression vector for mRNA translation in a cell-free system. FEBS Lett. 359:89-92.

12.Kawarasaki, Y., T. Kawai, H. Nakano and T. Yamane. 1995. A long-lived batch reaction system of cell-free protein synthesis. Anal. Biochem. 226:320-324.

13.Kawarasaki, Y., H. Nakano and T. Yamane. 1998. Phosphatase-immunodepleted cell-free protein synthesis system. J. Biotechnol. 61:199-208.

14.Kigawa, T., Y. Muto and S. Yokoyama. 1995. Cell-free synthesis and amino acid-selective stable isotope labeling of proteins for NMR analysis. J. Biomol. NMR 6:129-134.

15.Kigawa, T., T. Yabuki, Y. Yoshida, M. Tsutsui, Y. Ito, T. Shibata and S. Yokoyama. 1999. Cell-free production and stable-isotope labeling of milligram quantities of proteins. FEBS Lett. 442:15-19.

16.Kim, D.M. and C.Y. Choi. 1996. A semicontinuous prokaryotic coupled transcription/ translation system using a dialysis membrane. Biotechnol. Prog. 12:645-649.

17.Kim, D.M., T. Kigawa, C.Y. Choi and S. Yokoyama. 1996. A highly efficient cell-free protein synthesis system from Escherichia coli. Eur. J. Biochem. 239:881-886.

18.LaemmLi, D.K. 1970. Cleavage of structural proteins during the assembly of the head of bacteriophage T4. Nature 227:680-685.

19.Lowry, O.H., N.J. Rosebrough, A.L. Farr and R.J. Randall. 1951. Protein measurement with the Folin phenol reagent. J. Biol. Chem. 193:265-275.

20.Morozov, I. Yu., V.I. Ugarov, A.B. Chetverin and A.S. Spirin. 1993. Synergism in replication and translation of messenger RNA in a cell-free system. Proc. Natl. Acad. Sci. USA 90:9325-9329.

21.Munishkin, A.V., L.A. Voronin, V.I. Ugarov, L.A. Bondareva, H.V. Chetverina and A.B. Chetverin. 1991. Efficient templates for $Q \beta$ replicase are formed by recombination from heterologous sequences. J. Mol. Biol. 221:463472.

22.Nakano, H., T. Tanaka, Y. Kawarasaki and T. Yamane. 1994. An increased rate of cellfree protein synthesis by condensing wheat- germ extract with ultrafiltration membranes. Biosci. Biotechnol. Biochem. 58:631-634.

23.Olins, P.O. and S.H. Rangwala. 1989. A novel sequence element derived from bacteriophage T7 mRNA acts as an enhancer of translation of the lacZ gene in Escherichia coli. J. Biol. Chem. 264:16973-16976.

24.Ryabova, L.A., L.M. Vinokurov, E.A. Shekhovtsova, Yu.B. Alakhov and A.S. Spirin. 1995. Acetyl phosphate as an energy source for bacterial cell-free translation systems. Anal. Biochem. 226:184-186.

25.Ryabova, L., E. Volianik, O. Kurnasov, A. Spirin, Y. Wu and F.R. Kramer. 1994. Coupled replication-translation of amplifiable messenger RNA. A cell-free protein synthesis that mimics viral infection. J. Biol. Chem. 269:1501-1505.

26.Ryabova, L.A., I.Yu. Morozov and A.S. Spirin. 1998. Continuous-flow cell-free translation, transcription-translation, and replication-translation systems. Methods Mol. Biol. 77:179-193.

27.Sambrook, J., E.F. Fritsch and T. Maniatis. 1989. Molecular Cloning: A Laboratory Manual, 2nd ed. CSH Laboratory Press, Cold Spring Harbor, NY.

28.Schmidt, T.G.M., J. Koepke, R. Frank and A. Skerra. 1996. Molecular interaction between the Strep-tag affinity peptide and its cognate target streptavidin. J. Mol. Biol. 255:753-766.

29.Schmidt, T.G.M. and A. Skerra. 1993. The random peptide library-assisted engineering of a C-terminal affinity peptide, useful for the detection and purification of a functional Ig Fv fragment. Protein Eng. 6:109-122.

30.Schmidt, T.G.M. and A. Skerra. 1994. Onestep affinity purification of bacterially produced proteins by means of the "Strep-tag" and immobilized recombinant core streptavidin. J. Chromatogr. A 676:337-345.

31.Shine, J. and L. Dalgarno. 1974. The 3'-terminal sequence of Escherichia coli $16 \mathrm{~S}$ ribosomal RNA: complementarity to nonsense triplets and ribosome binding sites. Proc. Natl. Acad. Sci. USA 71:1342-1346.

32.Spirin, A.S. 1992. Cell-free protein synthesis bioreactors, p. 31-43. In P. Todd, S.K. Sikdar and M. Bier (Eds.), Frontiers in Bioprocessing II. American Chemical Society, Washington, DC.

33.Spirin, A.S., V.I. Baranov, L.A. Ryabova, S.Yu. Ovodov and Yu. B. Alakhov. 1988. A continuous cell-free translation system capable of producing polypeptides in high yield. Science 242:1162-1164.

34.Studier, F.W. and B.A. Moffatt. 1986. Use of bacteriophage T7 RNA polymerase to direct selective high-level expression of cloned genes. J. Mol. Biol. 189:113-130.

35.Ugarov, V.I., I. Yu. Morozov, G.Y. Jung, A.B. Chetverin and A.S. Spirin. 1994. Expression and stability of recombinant RQ-mRNAs in cell-free translation systems. FEBS Lett. 341:131-134.

36.Voss, S. and A. Skerra. 1997. Mutagenesis of a flexible loop in streptavidin leads to higher affinity for the Strep-tag II peptide and improved performance in recombinant protein purification. Protein Eng. 10:975-982.

37.Zubay, G. 1973. In vitro synthesis of protein in microbial systems. Annu. Rev. Genet. 7:267-287.

Received 23 June 1999; accepted 20 September 1999.

Address correspondence to:

Dr. Alexander B. Chetverin Institute of Protein Research Russian Academy of Sciences 142292 Pushchino

Moscow Region, Russia

Internet:alexch@vega.protres.ru 